\title{
Spatial Interpolation of Historical Seasonal Rainfall Indices over Peninsular Malaysia
}

\author{
Zulkarnain Hassan ${ }^{1, *}$, Ahmad Haidir ${ }^{1}$, Farah Naemah Mohd Saad ${ }^{1}$, Afizah Ayob ${ }^{1}$, \\ Mustaqqim Abdul Rahim ${ }^{1}$, and Zuhayr Md. Ghazaly ${ }^{1}$ \\ ${ }^{1}$ School of Environmental Engineering, Universiti Malaysia Perlis, Kompleks Pusat Pengajian Jejawi \\ 3, 02600 Arau, Perlis, Malaysia.
}

\begin{abstract}
The inconsistency in inter-seasonal rainfall due to climate change will cause a different pattern in the rainfall characteristics and distribution. Peninsular Malaysia is not an exception for this inconsistency, in which it is resulting extreme events such as flood and water scarcity. This study evaluates the seasonal patterns in rainfall indices such as total amount of rainfall, the frequency of wet days, rainfall intensity, extreme frequency, and extreme intensity in Peninsular Malaysia. 40 years (19752015) data records have been interpolated using Inverse Distance Weighted method. The results show that the formation of rainfall characteristics are significance during the Northeast monsoon (NEM), as compared to Southwest monsoon (SWM). Also, there is a high rainfall intensity and frequency related to extreme over eastern coasts of Peninsula during the NEM season.
\end{abstract}

\section{Introduction}

Evaluation of rainfall behaviour has drawn an attention throughout the world [1]. The relationship between rainfall and climate has become an intensive study nowadays since the climate change is likely to cause changing the magnitudes, frequencies, and intensities of rainfall as well its seasonal variability and distributions [2,3]. Therefore, the effect of these changes is needed to focus on the areas that are already vulnerable to rainfall characteristics due to geographical position and prominent diurnal variability in rainfall such as the coastal regions of southeast Asia [4] including Malaysia.

Many recent studies have evaluated historical rainfall and rainfall-related extremes in Malaysia such as Deni et al. [5]; Suhaila et al. [1]; Mayowa et al. [3]; and Syafrina et al. [6]. All these studies are analysed rainfall pattern and trend over Peninsular Malaysia based on only a few stations. However, the data is not up-to-date and limited to some stations, which do not reflect the current pattern of rainfall characteristics over the Peninsula.

This study aims to spatial interpolate of historical seasonal rainfall indices based on recent 40 years (1975-2015) daily rainfall data series collected from 37 stations located over Peninsular Malaysia. Rainfall indices including rainfall-related extremes such as total

\footnotetext{
* Corresponding author: zulkarnainh@unimap.edu.my
} 
amount of rainfall, frequency of wet days and rainfall intensity, extreme frequency, and extreme intensity are used in this study.

\section{Materials and methods}

Peninsular Malaysia is known as West Malaysia, is a part of Malaysia which lies on the Malay Peninsula and surrounding islands. With an area of 130,598 square kilometres, it shares a land border with Thailand in the north and Singapore in the south. The climate of Peninsular Malaysia is described by four seasons, namely two monsoon seasons and two inter-monsoon seasons. In this study, the Southwest monsoon (SWM) occurs from May to August while the Northeast monsoon (NEM) from November to February were used as the main seasons for the rainfall indices evaluation.

\subsection{Rainfall stations}

The rainfall stations in each of the region are chosen according to the homogenous of data produce in the rainfall stations and the completeness of data series based on the study period of 1975 to 2015 . The details of 38 rainfall stations and their locations are shown in Table 1 and Fig. 1, respectively.

\subsection{Rainfall indices}

The rainfall indices are designed to explain the changes of the variety aspects in the rainfall distribution. The rainfall indices used in this study to explain the rainfall distribution: total amount of rainfall (TAR) is the total amount of rainfall value on each season, frequency wet days (FWD) is the frequency of wet days that are defined as rainfall day with at least $1 \mathrm{~mm}$, rainfall intensity (RI) is the average amount of rainfall annually, extreme frequency (XF) is the frequency of wet days exceeding the 95th percentile, and extreme intensity (XI) is the rainfall intensity exceeding the 95 th percentile.

\subsection{Inverse Distance Weighted interpolation method}

Inverse Distance Weighted (IDW) interpolation method is used for the mapping of the spatial pattern of rainfall indices. Quantum GIS (QGIS) under spatial analysis is used for this purpose. IDW is a point based interpolation method, in which widely used for surface interpolation and has a point influence that decreases with each point distance [7]. The details of the IDW method can be referred to Harman et al. [8].

\section{Results}

\subsection{Total Amount of Rainfall}

The detail of spatial distribution of the total amount of rainfall (TAR) on each season is shown in Fig. 2. It can be seen that the large of TAR is happened on NEM season (Fig. 2a), as compared to SWM (Fig. 2b). During the NEM season, the large value of the TAR can be seen in the area of eastern regions, with the range $1174 \mathrm{~mm}$ to $1972 \mathrm{~mm}$. The largest of the TAR value is recorded at Station E5, with the value of $1972 \mathrm{~mm}$. On the SWM season, it can be seen that a small area at southern region are given a large of the TAR value, with the 
largest value is $967 \mathrm{~mm}$ at Station S3 (Pintu Kawalan Tg. Agas). From the record, the lowest of TAR value is happened at Londah, Negeri Seremban (Station S8), with the value of $228 \mathrm{~mm}$ and $143 \mathrm{~mm}$ for NEM and SWM seasons, respectively.

Table 1. Rainfall stations.

\begin{tabular}{|c|c|c|c|c|c|}
\hline States & $\begin{array}{c}\text { Station } \\
\text { Code }\end{array}$ & Station Details & Station ID. & $\begin{array}{l}\text { Lat. } \\
\left({ }^{\circ} \mathrm{N}\right)\end{array}$ & $\begin{array}{l}\text { Long. } \\
\left({ }^{\circ} \mathrm{E}\right)\end{array}$ \\
\hline \multirow{5}{*}{ Kedah } & N1 & Kg. Jelutong & 6005044 & 6.0458 & 100.5042 \\
\hline & N2 & Komplek Rumah Muda & 6108001 & 6.1056 & 100.8472 \\
\hline & $\mathrm{N} 3$ & Jabatan Penjara & 5604002 & 5.6292 & 100.4861 \\
\hline & N4 & Pulai & 5609074 & 5.6750 & 100.9150 \\
\hline & N5 & Rumah Penjaga JPS & 5105106 & 5.1278 & 100.5069 \\
\hline \multirow{3}{*}{ Kelantan } & E8 & Gua Musang & 4819027 & 6.4458 & 100.1875 \\
\hline & E9 & Ladang Kuala Nal & 5521050 & 6.4306 & 100.2708 \\
\hline & E10 & Station Pertanian Melor & 5922001 & 6.6569 & 100.3097 \\
\hline \multirow[b]{2}{*}{ Melaka } & $\mathrm{S} 1$ & Hospital Jasin & 2324033 & 5.3917 & 100.2125 \\
\hline & S2 & $\begin{array}{l}\text { Jambatan Sungai } \\
\text { Simpang Empat }\end{array}$ & 2421003 & 5.3756 & 100.4756 \\
\hline \multirow{5}{*}{ Pahang } & E1 & Rumah Rehat Rompin & 2834181 & 4.8792 & 101.9694 \\
\hline & E2 & Permatang Pauh & 3433105 & 5.5708 & 102.1639 \\
\hline & E3 & Paya Besar & 3732020 & 5.9639 & 102.2917 \\
\hline & E4 & Peri Jerantut & 3924071 & 2.8111 & 103.4944 \\
\hline & W10 & $\begin{array}{l}\text { Ladang Teh Cameron } \\
\text { Highlands }\end{array}$ & 4514032 & 3.4694 & 103.3833 \\
\hline \multirow{4}{*}{ Perak } & W1 & Rumah JPS Sungai Meng & 4011139 & 3.7722 & 103.2806 \\
\hline & W2 & JPS Telok Sena & 4209093 & 3.9625 & 102.4278 \\
\hline & W3 & $\begin{array}{l}\text { Ladang Kuda Keb. Ulu } \\
\text { Kinta }\end{array}$ & 4611001 & 5.0708 & 103.0139 \\
\hline & W4 & Pekan lenggong & 5109070 & 4.2319 & 103.4222 \\
\hline \multirow{3}{*}{ Perlis } & N6 & Padang Katong & 6401002 & 5.3181 & 103.1333 \\
\hline & N7 & Arau & 6402007 & 4.5167 & 101.4167 \\
\hline & $\mathrm{N} 8$ & Padang Besar & 6603002 & 4.0056 & 101.1028 \\
\hline Penang & N9 & Kolam Air Bukit Berapit & 5304045 & 4.6806 & 101.1694 \\
\hline \multirow{4}{*}{ Selangor } & W5 & $\begin{array}{l}\text { Pejabat JPS Sungai } \\
\text { Manggis }\end{array}$ & 2815001 & 5.1194 & 100.9833 \\
\hline & W6 & $\begin{array}{l}\text { Ladang West Pulau } \\
\text { Carey }\end{array}$ & 2913121 & 2.8264 & 101.5417 \\
\hline & W7 & Stor JPS Tg. Karang & 3411017 & 2.9111 & 101.3583 \\
\hline & W8 & $\begin{array}{l}\text { Rumah Pam JPS Bagan } \\
\text { Terap }\end{array}$ & 3710006 & 3.4236 & 101.1733 \\
\hline \multirow{3}{*}{ Terengganu } & E5 & Hospital Kuala Berang & 5030039 & 3.7286 & 101.0831 \\
\hline & E6 & JPS Kemaman & 4234109 & 3.1514 & 101.6847 \\
\hline & E7 & $\begin{array}{l}\text { Stor JPS Kuala } \\
\text { Terengganu }\end{array}$ & 5331048 & 2.3083 & 102.4319 \\
\hline $\begin{array}{l}\text { Kuala } \\
\text { Lumpur }\end{array}$ & W9 & $\begin{array}{l}\text { JPS Wilayah } \\
\text { Persekutuan }\end{array}$ & 3116003 & 2.4389 & 102.1861 \\
\hline \multirow{3}{*}{ Johor } & S3 & Pintu Kawalan Tg. Agas & 2025001 & 1.4708 & 103.7528 \\
\hline & S4 & Stor JPS Johor Bharu & 1437116 & 1.6264 & 103.2028 \\
\hline & S5 & Pintu Kawalan Tampok & 1632096 & 2.0514 & 102.5778 \\
\hline \multirow{3}{*}{$\begin{array}{l}\text { Negeri } \\
\text { Sembilan }\end{array}$} & S6 & Hospital Port Dickson & 2517033 & 2.5306 & 101.7972 \\
\hline & S7 & Kg. Bahru Pantai & 2720041 & 2.6389 & 102.5944 \\
\hline & S8 & Londah & 2625084 & 2.7850 & 101.9950 \\
\hline
\end{tabular}




\subsection{Frequency wet days}

In general, more than $70 \%$ of Peninsular Malaysia is facing a high number of frequency wet days (FWD) for both monsoons, as shown in Fig. 3. It can be seen that the eastern and western coasts of the Peninsular are facing a high number of FWD, with the range between 61 days to 70 days as compared with other regions. During the NEM season (Fig. 3a), several areas of the northern and southern regions are recorded with a lower number of FWD, with the lowest value of 26 days at $\mathrm{Kg}$. Jelutong (Station N1). This pattern is also displayed at Londah (Station S8), in which gives a low value of FWD on the NEM and SWM seasons with the value of 31 days and 26 days, respectively.

\subsection{Rainfall intensity}

Rainfall intensity (RI) or mean rainfall amount on wet days for the Peninsular Malaysia is displayed in Fig. 4. It shows that the high value of RI can be seen on the east coast of Peninsular, including Kelantan, Pahang, and Terengganu with the range of 30-36 mm/day during the NEM season (Fig. 4a). The high of RI during the NEM season is also recorded near to Tg. Agas at Johor (Stations 5) with the range between $25 \mathrm{~mm} /$ day to $29 \mathrm{~mm} /$ day. During the SWM season, the high of the RI values are seen over southern coast, especially at Melaka (Station S1) and Johor (Station S5) with the value of $20 \mathrm{~mm} /$ day to $27 \mathrm{~mm} /$ day. The lowest of RI value is recorded at Ladang Teh Cameron Highlands (Station W10), Pahang and Bagan Terap (Station W8), Selangor during the NEM and SWM seasons, respectively with the value of $11 \mathrm{~mm} /$ day.

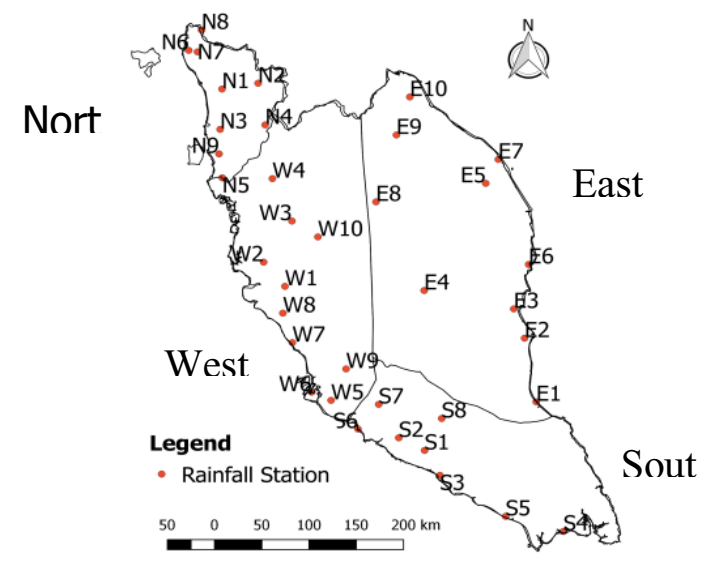

Fig. 1. Locations of rainfall stations.

\subsection{Extreme frequency of wet days}

Fig. 5 shows the extreme frequency (XF) of the Peninsular Malaysia obtained from the 40 years data (1975-2015). Result reveals that XF is recorded more than 3 days/year during both monsoons for over $80 \%$ of the Peninsular. The highest XF is obtained along eastern coasts during the NEM season, in which the highest value of XF is 5 days/year. 


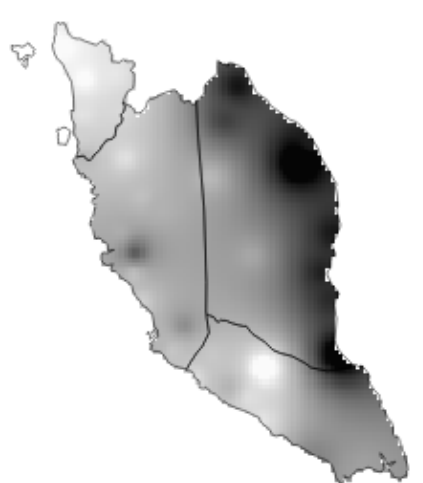

(a)

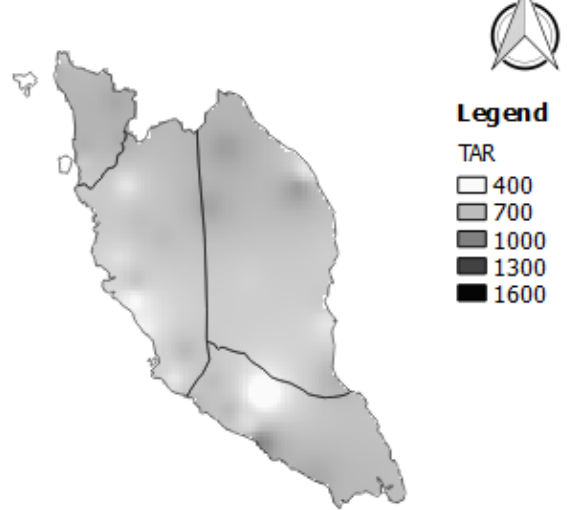

${ }_{50}\left(\mathbf{b}_{0}\right)_{50} 100150200 \mathrm{~km}$

Fig. 2. Spatial pattern in TAR value on a) NEM and b) SWM.

\subsection{Extreme intensity}

Extreme intensity (XI) can be defined as a rainfall intensity which exceeds 95th percentile. As shown in Fig. 6, it can be seen that the XI is high in the NEM season as compared with the SWM. During the NEM, the high of XI are recorded at the eastern coasts, with the range between 119 and $151 \mathrm{~mm} /$ day. The lowest of XI value for both seasons is recorded at Ladang Teh Cameron Highlands (Station W10), Pahang with the value of $44 \mathrm{~mm} /$ day.

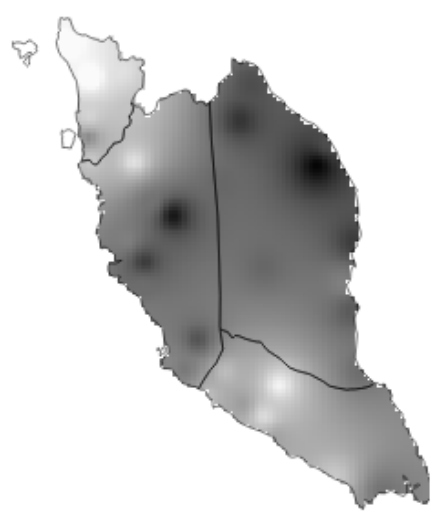

(a

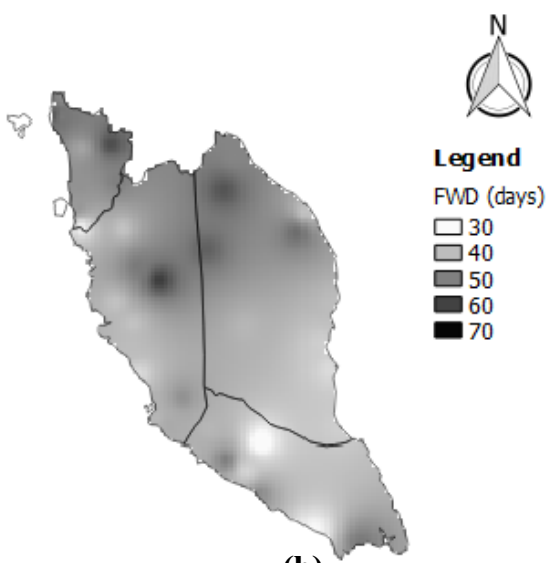

(b) $50 \quad 50100150200 \mathrm{~km}$

Fig. 3. Spatial pattern in FWD value on a) NEM and b) SWM. 


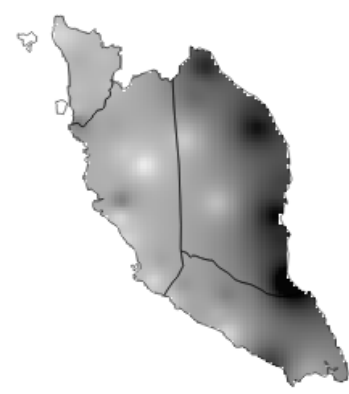

(a

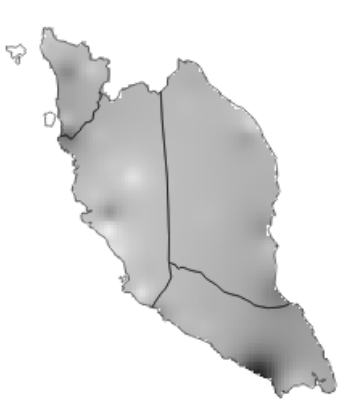

(h)

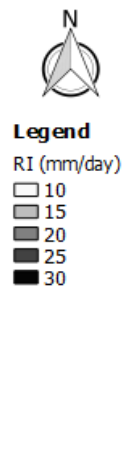

$50 \quad 0 \quad 50 \quad 100 \quad 150 \quad 200 \mathrm{~km}$

Fig. 4. Spatial pattern in RI value on a) NEM and b) SWM.

\section{Discussions}

Based on the results of the rainfall indices, it can be said that the Peninsular Malaysia, especially along eastern coasts is facing a high rain intensity and duration during the NEM season as compared to the SWM since all rainfall indices tend to be higher than those during another season. This situation occurs due to interaction with the land since the northeasterly winds bring heavy rainfall when passage over the South China Sea [9-10]. The result is similar with Suhaila et al. [1], which identified that some areas at the eastern region have received a high intensity of rainfall amount as compared to other regions in the Peninsula.

Conversely, less rainfall during the SWM is happenned because the southwesterly winds which come to Peninsula from Sumatra, Indonesia are brought low of the rainfall intensity and the wind speed is literally slow due to the high mountain ranges over Sumatra that create rain sheltering effects for Peninsular Malaysia [11]. During this season, the eastern coasts of the Peninsular is also recorded less rainfall as compared to the western coast since the presence of Titiwangsa range which limits the in-land penetration of the southwesterly winds [12].

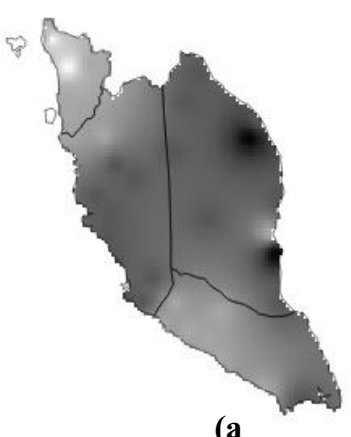

(a
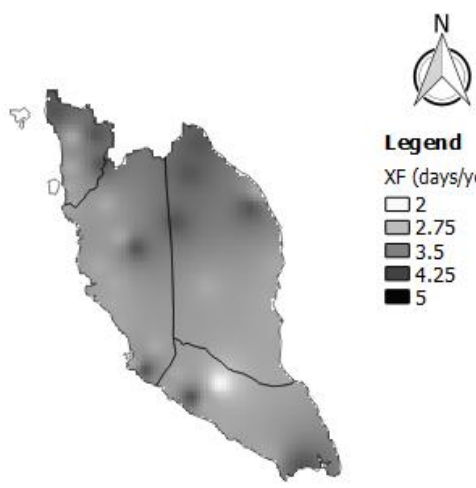

Legend

XF (days/year)

$\square 2$
$\square 2.75$

$\square 3.5$

4.25

Fig. 5. Spatial pattern in XF value on a) NEM and b) SWM. 


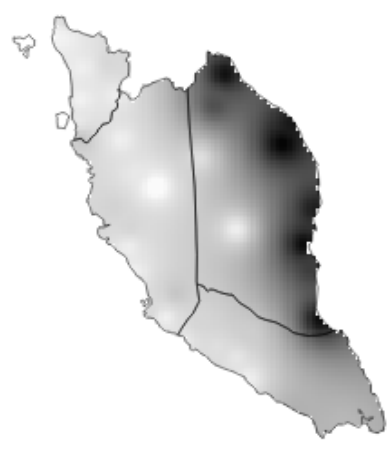

(a)

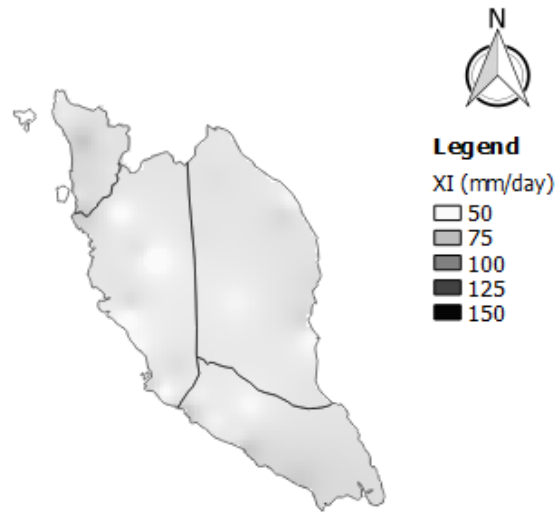

$50 \quad\left(_{50}(\mathbf{b})_{100} 150200 \mathrm{~km}\right.$

Fig. 6. Spatial pattern in XI value on a) NEM and b) SWM.

This study also found that Londah (Station S8) at southern region is the driest station on the Peninsula. Although it is found that northern region is a dry region as illustrated in the result and claimed as the driest region in Peninsular Malaysia by Suhaila et al. [1], still the area at Londah give the driest record. This difference occurs probably due to the effect of climate change toward the current climate in which increase the drying period at the area of southern region.

In term of extreme rainfall in Peninsular Malaysia, the study found that several areas especially east coastal like Kelantan, Pahang and Terengganu coasts had to face a long heavy rainfall in which high value of XF. Those records indicated that the areas had to be facing a possible flood due to high rainfall duration and intensity. Study from Leman et al. [13] also found that the areas of the east coast of the Peninsular are occurred the major flood event for the sixties of the last century due to abnormally heavy rainfall intensity especially during the NEM season.

\section{Conclusions}

Seasonal patterns have been interpolated by using five rainfall indices on four regions in Peninsular Malaysia for the period of 1975-2015. It can be concluded that the highest mean for each indices are on the eastern coasts of the Peninsula during the NEM season. During the SWM, it has less significance in characterizing the rainfall pattern over Peninsula and greater impact in the southern and western regions. The driest part is likely to be located in the southern region of Peninsula. In term of extreme rainfall, both seasons give a high rainfall frequency and less than $30 \%$ of the regions have faced the high rainfall intensity.

Results of this study will be aid guidance to the understanding the pattern of rainfall characteristics in Peninsular Malaysia. It also will help to increase effectiveness in risk (such as crop, irrigation, and flood) planning purpose and policy. Nevertheless, further studies should be conducted to consider more rainfall indices and further analyses such as trend and re-sampling, in which should display the significant trends to each station are recommended.

The authors thank the Department of Irrigation and Drainage Malaysia (DID), Malaysia for providing the data. 


\section{References}

1. J. Suhaila, S. Mohd Deni, W.Z. Wan Zin, A.Z. Jemain, Sains Malaysiana 39, 533-542 (2010)

2. X.J. Wang, J.Y. Zhang, S. Shahid, E.H. Guan, Y.X. Wu, J. Gao, R.M. He, R. M. Mitigation \& Adapt. Strategies for Global Change 21(1), 81-99 (2016)

3. O.O. Mayowa, S.H. Pour, S, Shahid, M. Mohsenipour, S, Harun, A. Heryansyah, T. Ismail, J. Earth Syst. Sci. 124(8), 1609-1622 (2015)

4. H. Chang, W.T. Kwon, Environ. Res. Lett. 2, 045012 (2007)

5. S.M. Deni, J. Suhaila, W.Z. Wan Zin, A.A. Jemain, Theor. Appl. Climatol. 99, 357-371 (2010)

6. A.H. Syafrina, M.D. Zalina, A. Norzaida, A. J. of Appl. Sci. 14(3), 392-405 (2017)

7. P.M. Bartier, C.P. Keller, Comp. \& Geosci. 22(7), 195-799 (1996).

8. B.I. Harman, H. Koseoglu, C.O. Yigit, Appl. Acous. 112, 147-157 (2016)

9. C.P. Chang, P.A. Harr, H.J. Chen, Mon. Weather Rev. 113, 489-503 (2005)

10.E. Salimum, F.T. Tangang, L. Juneng, Meteorol. Atmos. Phys. 107, 33-49 (2010)

11.Z.A. Mohtar, A.S. Yahaya, F. Ahmad, S. Suri, M.H. Halim, J. of Civil Eng. Res. 4(3A), 222-227 (2014)

12.C.L. Wong, J. Liew, Z. Yusop, T. Ismail, R. Venneker, S. Uhlenbrook, Water 8, 500 (2016)

13.A.M. Leman, K.A. Rahman, M,N.M. Salleh, D. Feriyanto, S.N.H. Muhammad, The Soc. Sci. 12(5), 781-786 (2017) 